\title{
Diet in the Aetiology of Ulcerative Colitis: A European Prospective Cohort Study
}

\author{
Andrew R. Hart ${ }^{a, l}$ Robert Luben ${ }^{b}$ Anja Olsen ${ }^{c}$ Anne Tjonneland ${ }^{c}$ Jakob Linseisen ${ }^{d}$ \\ Gabriele Nagel $^{d}$ Göran Berglund ${ }^{e}$ Stefan Lindgren ${ }^{e}$ Olof Grip ${ }^{e}$ Timothy Key $^{f}$ \\ Paul Appleby $^{f}$ Manuela M. Bergmann ${ }^{g}$ Heiner Boeing ${ }^{g}$ Göran Hallmans ${ }^{h}$ Åke Danielsson ${ }^{h}$ \\ Richard Palmqvist $^{\text {h }}$ Hubert Sjodin $^{\text {h }}$ Gun Hägglund $^{\text {h }}$ Kim Overvad $^{i}$ Domenico Palli ${ }^{j}$

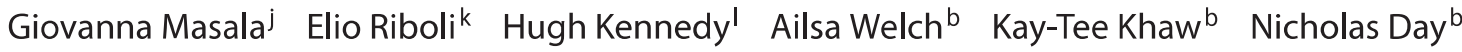 \\ Sheila Bingham ${ }^{b}$

\begin{abstract}
${ }^{a}$ Department of Population Health, School of Medicine, Health Policy and Practice, University of East Anglia, Norwich, and ${ }^{b}$ Strangeways Research Laboratory, Institute of Public Health, University of Cambridge, Cambridge, UK; 'Institute of Cancer Epidemiology, Danish Cancer Society, Copenhagen, Denmark; ${ }^{\mathrm{d}}$ Division of Clinical Epidemiology, DKFZ-German Cancer Research Centre, Heidelberg, Germany; ${ }^{e}$ Department of Clinical Sciences, University Hospital, Malmö, Sweden; ${ }^{f}$ Cancer Research UK Epidemiology Unit, University of Oxford, Oxford, UK; ${ }^{9}$ Department of Epidemiology, German Institute of Human Nutrition, Potsdam, Germany; ${ }^{\text {h}}$ Department of Medicine (GI Unit) and Department of Nutritional Research and Medical Biosciences, Umeå University, Umeå, Sweden; 'Department of Clinical Epidemiology, University of Aarhus, Aarhus, Denmark; 'Molecular and Nutritional Epidemiology Unit, Cancer Research and Prevention Centre, Florence, Italy; ${ }^{k}$ Division of Epidemiology, Imperial College London, London, and 'Norfolk and Norwich University Hospital NHS Trust, Norwich, UK
\end{abstract}

\begin{abstract}
Background/Aims: The causes of ulcerative colitis are unknown, although it is plausible that dietary factors are involved. Case-control studies of diet and ulcerative colitis are subject to recall biases. The aim of this study was to examine the prospective relationship between the intake of nutrients and the development of ulcerative colitis in a cohort study. Methods: The study population was 260,686 men and women aged 20-80 years, participating in a large European prospective cohort study (EPIC). Participants were residents in the UK, Sweden, Denmark, Germany or Italy. Information on diet was supplied and the subjects were followed up for the development of ulcerative colitis. Each incident case was matched with four controls and dietary variables were di-
\end{abstract}

vided into quartiles. Results: A total of 139 subjects with incident ulcerative colitis were identified. No dietary associations were detected, apart from a marginally significant positive association with an increasing percentage intake of energy from total polyunsaturated fatty acids (trend across quartiles OR $=1.19(95 \% \mathrm{Cl}=0.99-1.43) \mathrm{p}=0.07)$. Conclusions: No associations between ulcerative colitis and diet were detected, apart from a possible increased risk with a higher total polyunsaturated fatty acid intake. A biological mechanism exists in that polyunsaturated fatty acids are metabolised to pro-inflammatory mediators.

\section{Introduction}

Ulcerative colitis is a chronic condition producing distressing symptoms - it causes an impairment in patients' quality of life, and is associated with an increased risk of 
fatal complications such as perforation and colorectal cancer [1]. The causes of ulcerative colitis are unknown although it is plausible that diet could be involved. Hypothetically, dietary constituents could influence the risk of colonic inflammation by several mechanisms which include direct contact with the colonic mucosa, by affecting the chemical composition of mucosal cell membranes or by altering the balance of intestinal flora. In case-control studies, which have reported the dietary intake prior to the diagnosis of ulcerative colitis, the results have been conflicting with several not showing any affect on risk [2-6] and others reporting either an increased [7-15] or decreased risk $[10-13,15,16]$. An increased risk has been reported for carbohydrate and starch [7], cereal products [10], sugar [17], fat [10, 12, 13], cholesterol [12], protein [7], monounsaturated and polyunsaturated fatty acids $[9,12]$, fast foods [11], cola drinks [14], chocolate [14] and sweets [15]. A decreased risk was reported for fruit and vegetable fibre $[10,16]$, vitamin C $[12,15]$ vitamin $\mathrm{E}[13]$ and coffee $[11,15]$. Such case-control studies provide important information, particularly if the interval between diagnosis and recruitment into the study is short, so that the presymptomatic diet is accurately reported. However, their limitation is recall bias where patients are more focused on what they eat now than healthy controls and therefore tend to record their current post-diagnosis diet, rather than that which preceded their symptoms and which may have lead to the development of the disease. Cohort studies remove this important bias, although to date none have been conducted specifically investigating inflammatory bowel disease. The aim of this present investigation was to perform the first large prospective investigation of diet and ulcerative colitis using the EPIC Study cohort (European Prospective Investigation into Cancer and Nutrition) [18]. EPIC has recruited 519,978 volunteers in 23 centres in 10 countries who have provided information on diet and lifestyle and are being followed up to ascertain who develops cancer, heart disease [19] and other illnesses, such as ulcerative colitis.

\section{Methods}

Eight cohorts in five countries collaborated in this investigation of diet and ulcerative colitis. The EPIC sub-cohorts participating constituted 260,686 men and women in the age range 2080 years, although most centres recruited middle-aged volunteers (table 1). Participants provided information on diet, physical activity, and other lifestyle factors such as smoking and drinking habits as well as medication. Subjects gave informed consent for their data to be used for research and the study protocols were approved by ethical committees in each country. Diet was measured by country-specific food frequency questionnaires (FFQs) that were designed to capture local dietary habits and to give high compliance. In all centres, the FFQs were validated against 24hour recall questionnaires and most centres also compared their questionnaire data against plasma and urinary biomarkers for specific nutrients including vitamin $\mathrm{C}$, vitamin $\mathrm{E}$ and protein (as nitrogen) [20, 21]. In Norfolk, UK, the questionnaires were also validated against food diaries before the commencement of the main EPIC Study [22]

Participants who developed ulcerative colitis were identified from disease registries of inflammatory bowel disease in Italy, Sweden and Denmark, from follow-up questionnaires in Germany and the Oxford cohort, and in the Norfolk cohort by a combination of follow-up questionnaires, hospital in-patient data and pathology databases. For each case, physicians were asked to confirm the diagnosis of ulcerative colitis according to whether there was endoscopic, radiological and histological evidence of disease. Cases in which the diagnosis was uncertain, i.e. indeterminate colitis was excluded from this study. Information was collected on the extent of disease. Prevalent cases of ulcerative colitis at recruitment were excluded, as well as participants who were diagnosed less than 18 months after recruitment into the EPIC Study. This helped to ensure that the dietary data reflected dietary intake prior to the development of symptoms. Incident cases were identified up to the end of June 2004 for most centres.

In the analysis, each case was matched with four randomly selected controls (from the same centre) of the same gender, date of birth ( \pm 6 months) and date of recruitment into EPIC ( \pm 3 months) and who were alive on the date when the matched case was diagnosed. The last two matching criteria ensured that the periods of follow-up were similar for both cases and controls. An analysis was performed using conditional logistic regression (STATA software) in which levels of dietary intake were divided into gender-specific quartiles from the distribution across both cases and controls. For macronutrients, intake was expressed as a percentage of total energy intakes, rather than absolute intake, as the former has been shown to correlate more closely with absolute values of intake when measured from weighed records [22]. Furthermore, this method helps to account for differences in factors which can affect dietary intake including body mass index, metabolic rate and physical activity. For micronutrient intake, the analysis was performed for absolute intake, adjusted for total energy intake as measured in $\mathrm{kJ} / \mathrm{day}$. The effect of smoking was assessed to see if this needed to be included as a confounder, as smoking reduces the risk of ulcerative colitis $[23,24]$

\section{Results}

A total of 139 incident cases were identified of which $51.1 \%(n=71)$ were women and $48.9 \%(n=68)$ were men. Age at diagnosis was known for 124 (89.2\%) cases with a median age of 58.8 years (range 28.0-80.8 years) and a median time between recruitment and diagnosis of 3.8 years (range $1.7-11.3$ years). Most cases (81.3\%) had the extent of their disease assessed by colonoscopy or barium enema, with $67.5 \%$ of these having left sided disease up to 
Table 1. Participating centres and characteristics of the cohorts

\begin{tabular}{|c|c|c|c|}
\hline Centre and country & Size of cohort & Nature of cohort & $\begin{array}{l}\text { Number of subjects with } \\
\text { incident ulcerative colitis }\end{array}$ \\
\hline $\begin{array}{l}\text { Oxford, } \\
\text { UK }\end{array}$ & 50,070 & $\begin{array}{l}\text { members of vegetarian societies and readers of health food } \\
\text { magazines, aged } 20-80 \text { years ( } 78 \% \text { women); recruited } \\
\text { between } 1994 \text { and } 1999 \\
\text { participants from general practice registers aged } 20-80 \text { years } \\
\text { ( } 73 \% \text { women); recruited between } 1993 \text { and 1997; cases } \\
\text { identified from follow-up questionnaires }\end{array}$ & 17 \\
\hline $\begin{array}{l}\text { Norfolk, } \\
\text { UK }\end{array}$ & 25,639 & $\begin{array}{l}\text { population-based cohort of men and women aged } 45-74 \\
\text { years; recruited between } 1993 \text { and 1997; cases identified from } \\
\text { follow-up questionnaires, in-patient admission data and } \\
\text { histopathology records }\end{array}$ & 25 \\
\hline $\begin{array}{l}\text { Heidelberg, } \\
\text { Germany }\end{array}$ & 25,540 & $\begin{array}{l}\text { population-based cohort of men aged } 45-65 \text { years and } \\
\text { women aged 35-65 years; recruited between } 1994 \text { and } 1998 \text {; } \\
\text { cases identified from follow-up questionnaires }\end{array}$ & 4 \\
\hline $\begin{array}{l}\text { Potsdam, } \\
\text { Germany }\end{array}$ & 27,548 & $\begin{array}{l}\text { population-based cohort, men and women, aged 35-64 years; } \\
\text { recruited between } 1994 \text { and 1998; cases identified from } \\
\text { follow-up questionnaires }\end{array}$ & 9 \\
\hline $\begin{array}{l}\text { Florence, } \\
\text { Italy }\end{array}$ & 13,583 & $\begin{array}{l}\text { population-based cohort, men and women aged } 34-64 \text { years; } \\
\text { recruited between } 1993 \text { and 1998; cases identified from } \\
\text { regional databases of inflammatory bowel disease }\end{array}$ & 8 \\
\hline $\begin{array}{l}\text { Umeå, } \\
\text { Sweden }\end{array}$ & 25,732 & $\begin{array}{l}\text { population-based cohort, men and women aged } 30-60 \text { years; } \\
\text { recruited between } 1992 \text { and 1996; cases identified from } \\
\text { regional databases of inflammatory bowel disease }\end{array}$ & 15 \\
\hline $\begin{array}{l}\text { Malmö, } \\
\text { Sweden }\end{array}$ & 28,098 & $\begin{array}{l}\text { population-based cohort, men and women aged } 45-69 \text { years; } \\
\text { recruited between } 1991 \text { and 1996; cases identified from } \\
\text { regional databases of inflammatory bowel disease }\end{array}$ & 21 \\
\hline $\begin{array}{l}\text { Aarhus, } \\
\text { Copenhagen, } \\
\text { Denmark }\end{array}$ & 57,053 & $\begin{array}{l}\text { population-based cohort of men and women aged 50-64 } \\
\text { years; recruited between } 1993 \text { and 1997; cases identified from } \\
\text { national databases of inflammatory bowel disease }\end{array}$ & 40 \\
\hline Total & 260,686 & & 139 \\
\hline
\end{tabular}

the splenic flexure. Confirmatory histology for ulcerative colitis was available for $70.5 \%$ of all cases. The cases were age and gender matched with 556 randomly selected controls. Data were available on smoking for $83.5 \%$ of cases $(\mathrm{n}=116)$.

For most nutrients, data were available for the analysis for at least $98 \%$ of subjects, with the exceptions being vitamin E (93\%) and carotene (83\%). No statistically significant associations were detected between the risk of ulcerative colitis and macronutrients or micronutrients (tables 2, 3). However, a marginally significant positive association between the risk of disease and percentage of total energy intake from total polyunsaturated fatty acid intake (PUFAs) was identified $(\mathrm{OR}=1.19,95 \% \mathrm{CI}=0.99$ 1.43 for trend across quartiles, $\mathrm{p}=0.07)$. This trend implies that for each one quartile higher level of intake the odds ratio for the risk of disease was 1.19 times higher than the lower quartile. The frequency of smoking was similar in cases and controls (24.5 vs. $24.1 \%, \chi^{2}=0.005$, $\mathrm{p}=0.94$ ) and adjusting for smoking had no effect on the associations.

\section{Discussion}

This is the first prospective study to investigate whether there is an association between incident cases of ulcerative colitis and diet. No statistically significant associations were detected between the risk of disease and nutrients. However, a marginally significant positive association was detected between the risk of ulcerative colitis and an increasing percentage intake of energy from total PUFAs, with an odds ratio for trend across quartiles of 1.19 (95\% CI $=0.99-1.43, \mathrm{p}=0.07)$. This association is supported by a plausible biological mechanism for PUFAs being involved in the aetiology of in- 
Table 2. Odds ratios for ulcerative colitis by quartile of intake of selected macronutrients

\begin{tabular}{|c|c|c|c|c|}
\hline Macro-nutrient & $\begin{array}{l}\text { Quartile of increasing } \\
\text { intake (number of cases } \\
\text { and controls) }\end{array}$ & $\begin{array}{l}\text { Quartile ranges } \\
\text { for women }\end{array}$ & $\begin{array}{l}\text { Quartile ranges } \\
\text { for men }\end{array}$ & $\begin{array}{l}\text { Odds ratios (plus } 95 \% \text { CIs) } \\
\text { for quartiles of percentage of energy intake } \\
\text { from macronutrients }\end{array}$ \\
\hline Energy intake & $\begin{array}{l}1(34,138) \\
2(31,141) \\
3(35,137) \\
4(37,133)\end{array}$ & $\begin{array}{l}3,126-6,578 \\
6,599-7,942 \\
7,971-9,645 \\
9,705-15,109\end{array}$ & $\begin{array}{c}3,863-8,104 \\
8,107-9,715 \\
9,719-11,690 \\
11,695-24,390\end{array}$ & $\begin{array}{l}1.00 \\
0.91(0.53-1.57) \\
1.07(0.62-1.83) \\
1.15(0.66-1.98) \\
\text { trend } \mathrm{OR}=1.06(0.89-1.26) \mathrm{p}=0.52\end{array}$ \\
\hline $\begin{array}{l}\text { Carbohydrate, \% of total energy } \\
\text { intake }\end{array}$ & $\begin{array}{l}1(36,136) \\
2(30,141) \\
3(29,143) \\
4(42,128)\end{array}$ & $\begin{array}{l}25.1-42.1 \\
42.2-47.8 \\
47.9-51.6 \\
51.7-72.4\end{array}$ & $\begin{array}{l}23.3-38.7 \\
38.8-43.9 \\
44.0-48.7 \\
48.8-65.3\end{array}$ & $\begin{array}{l}1.00 \\
0.67(0.37-1.22) \\
1.36(0.79-2.32) \\
1.12(0.63-1.97) \\
\text { trend } \mathrm{OR}=1.12(0.92-1.33) \mathrm{p}=0.26\end{array}$ \\
\hline Protein, $\%$ of total energy intake & $\begin{array}{l}1(38,134) \\
2(27,144) \\
3(45,127) \\
4(27,143)\end{array}$ & $\begin{array}{r}8.0-13.9 \\
14.0-15.5 \\
15.6-17.5 \\
17.6-32.6\end{array}$ & $\begin{array}{r}9.2-13.5 \\
13.6-15.0 \\
15.1-16.6 \\
16.8-24.1\end{array}$ & $\begin{array}{l}1.00 \\
1.28(0.77-2.15) \\
0.80(0.46-1.41) \\
0.79(0.44-1.42) \\
\text { trend } \mathrm{OR}=0.88(0.74-1.06) \mathrm{p}=0.20\end{array}$ \\
\hline Fat, $\%$ of total energy intake & $\begin{array}{l}1(37,135) \\
2(31,140) \\
3(37,135) \\
4(32,138)\end{array}$ & $\begin{array}{r}8.8-29.0 \\
29.0-33.0 \\
33.0-37.0 \\
37.0-53.0\end{array}$ & $\begin{array}{l}17.0-31.0 \\
31.0-34.0 \\
34.0-39.0 \\
39.0-56.0\end{array}$ & $\begin{array}{l}1.00 \\
1.35(0.79-2.30) \\
0.79(0.44-1.41) \\
1.13(0.65-1.99) \\
\text { trend OR }=0.99(0.82-1.18) \mathrm{p}=0.88\end{array}$ \\
\hline Alcohol, \% of total energy intake & $\begin{array}{l}1(37,135) \\
2(36,135) \\
3(31,141) \\
4(33,138)\end{array}$ & $\begin{array}{l}0.0-0.7 \\
0.8-2.7 \\
2.8-5.9 \\
6.0-22.4\end{array}$ & $\begin{array}{l}\quad 0-0.8 \\
0.9-2.7 \\
2.8-5.9 \\
6.0-35.0\end{array}$ & $\begin{array}{l}1.00 \\
0.98(0.57-1.66) \\
0.78(0.44-1.37) \\
0.84(0.46-1.52) \\
\text { trend OR }=0.93(0.76-1.12) \mathrm{p}=0.45\end{array}$ \\
\hline Starch, \% of total energy intake & $\begin{array}{l}1(37,135) \\
2(34,137) \\
3(33,139) \\
4(33,138)\end{array}$ & $\begin{array}{r}3.8-12.2 \\
12.7-19.9 \\
20.0-25.0 \\
25.1-43.2\end{array}$ & $\begin{array}{r}2.7-12.6 \\
12.7-19.9 \\
20.0-25.0 \\
25.1-46.7\end{array}$ & $\begin{array}{l}1.00 \\
0.62(0.26-1.52) \\
0.53(0.19-1.46) \\
0.52(0.19-1.46) \\
\text { trend } \mathrm{OR}=0.87(0.67-1.14) \mathrm{p}=0.33\end{array}$ \\
\hline Sugars, $\%$ of total energy intake & $\begin{array}{l}1(38,134) \\
2(33,138) \\
3(29,143) \\
4(37,134)\end{array}$ & $\begin{array}{r}3.4-13.5 \\
13.6-17.8 \\
17.9-23.1 \\
23.2-52.7\end{array}$ & $\begin{array}{r}2.4-13.6 \\
13.7-17.9 \\
18.0-23.1 \\
23.2-45.5\end{array}$ & $\begin{array}{l}1.00 \\
0.81(0.43-1.49) \\
0.69(0.36-1.32) \\
0.95(0.46-1.98) \\
\text { trend OR }=0.97(0.77-1.24) \mathrm{p}=0.83\end{array}$ \\
\hline $\begin{array}{l}\text { Saturated fatty acids, \% of total } \\
\text { energy intake }\end{array}$ & $\begin{array}{l}1(37,135) \\
2(35,136) \\
3(30,142) \\
4(35,136)\end{array}$ & $\begin{array}{r}1.9-10.3 \\
10.4-12.4 \\
12.5-15.4 \\
15.5-23.7\end{array}$ & $\begin{array}{r}4.5-10.3 \\
10.4-12.4 \\
12.5-15.4 \\
15.5-26.3\end{array}$ & $\begin{array}{l}1.00 \\
0.92(0.54-1.58) \\
0.75(0.42-1.32) \\
0.89(0.49-1.61) \\
\text { trend OR }=0.94(0.78-1.14) \mathrm{p}=0.55\end{array}$ \\
\hline $\begin{array}{l}\text { Monounsaturated fatty acids, } \% \text { of } \\
\text { total energy intake }\end{array}$ & $\begin{array}{l}1(37,135) \\
2(27,144) \\
3(36,136) \\
4(37,134)\end{array}$ & $\begin{array}{r}1.3-9.6 \\
9.7-11.4 \\
11.5-13.5 \\
13.6-25.9\end{array}$ & $\begin{array}{c}3.4-9.6 \\
9.7-11.3 \\
11.4-13.5 \\
13.6-22.6\end{array}$ & $\begin{array}{l}1.00 \\
0.70(0.40-1.23) \\
1.00(0.56-1.78) \\
1.10(0.57-2.14) \\
\text { trend } \mathrm{OR}=1.06(0.85-1.31) \mathrm{p}=0.62\end{array}$ \\
\hline $\begin{array}{l}\text { Polyunsaturated fatty acids, } \% \text { of } \\
\text { total energy intake }\end{array}$ & $\begin{array}{l}1(32,140) \\
2(28,143) \\
3(35,137) \\
4(42,129)\end{array}$ & $\begin{array}{l}1.1-4.0 \\
4.1-5.0 \\
5.1-6.4 \\
6.5-11.6\end{array}$ & $\begin{array}{l}2.2-4.0 \\
4.1-5.0 \\
5.1-6.5 \\
6.6-14.0\end{array}$ & $\begin{array}{l}1.00 \\
0.90(0.50-1.61) \\
1.21(0.68-2.17) \\
1.56(0.87-2.77) \\
\text { trend OR }=1.19(0.99-1.43) \mathrm{p}=0.07\end{array}$ \\
\hline $\begin{array}{l}\text { Fibre, g/day } \\
\text { (not \% of total energy intake) }\end{array}$ & $\begin{array}{l}1(31,142) \\
2(36,137) \\
3(36,137) \\
4(35,137)\end{array}$ & $\begin{array}{r}6.2-14.6 \\
14.7-17.9 \\
18.0-23.2 \\
23.3-47.1\end{array}$ & $\begin{array}{r}6.9-14.8 \\
14.9-19.4 \\
19.5-23.8 \\
23.9-45.5\end{array}$ & $\begin{array}{l}1.00 \\
1.23(0.70-2.16) \\
1.19(0.66-2.14) \\
1.12(0.59-2.11) \\
\text { trend } \mathrm{OR}=1.03(0.84-1.25) \mathrm{p}=0.80\end{array}$ \\
\hline
\end{tabular}


Table 3. Odds ratios for ulcerative colitis by quartile of intake of selected micronutrients, adjusted for energy intake

\begin{tabular}{|c|c|c|c|c|}
\hline Micro-nutrient & $\begin{array}{l}\text { Quartile of increasing intake } \\
\text { (number of cases and controls) }\end{array}$ & $\begin{array}{l}\text { Quartile ranges } \\
\text { for women }\end{array}$ & $\begin{array}{l}\text { Quartile ranges } \\
\text { for men }\end{array}$ & $\begin{array}{l}\text { Odds ratios (plus } 95 \% \text { CIs) for quartiles of } \\
\text { intake, adjusted for energy intake }\end{array}$ \\
\hline Vitamin C, mg/day & $\begin{array}{l}1(36,136) \\
2(40,132) \\
3(27,145) \\
4(34,136)\end{array}$ & $\begin{array}{c}30.4-74.5 \\
74.6-104.4 \\
104.6-143.6 \\
144.0-494.0\end{array}$ & $\begin{array}{c}23.6-64.9 \\
66.5-92.7 \\
93.1-128.2 \\
128.4-416.3\end{array}$ & $\begin{array}{l}1.00 \\
1.12(0.67-1.87) \\
0.69(0.39-1.21) \\
0.89(0.50-1.58) \\
\text { trend } \mathrm{OR}=0.92(0.76-1.10) \mathrm{p}=0.35\end{array}$ \\
\hline Vitamin $D, \mu \mathrm{g} /$ day & $\begin{array}{l}1(32,140) \\
2(38,134) \\
3(34,138) \\
4(33,137)\end{array}$ & $\begin{array}{l}0.2-2.2 \\
2.3-3.3 \\
3.4-4.8 \\
4.9-15.0\end{array}$ & $\begin{array}{l}0.3-3.0 \\
3.1-4.4 \\
4.5-6.7 \\
6.8-17.0\end{array}$ & $\begin{array}{l}1.00 \\
1.17(0.66-2.08) \\
0.97(0.52-1.84) \\
0.89(0.42-1.86) \\
\text { trend } \mathrm{OR}=0.94(0.75-1.20) \mathrm{p}=0.65\end{array}$ \\
\hline Vitamin E, mg/day & $\begin{array}{l}1(30,132) \\
2(32,129) \\
3(30,132) \\
4(37,124)\end{array}$ & $\begin{array}{c}2.0-6.1 \\
6.2-8.0 \\
8.1-11.2 \\
11.3-35.4\end{array}$ & $\begin{array}{c}2.9-6.6 \\
6.7-9.1 \\
9.2-12.4 \\
12.5-33.5\end{array}$ & $\begin{array}{l}1.00 \\
1.12(0.61-2.04) \\
1.05(0.55-1.99) \\
1.35(0.68-2.68) \\
\text { trend OR }=1.09(0.87-1.36) \mathrm{p}=0.45\end{array}$ \\
\hline Carotene, $\mu \mathrm{g} /$ day & $\begin{array}{l}1(32,115) \\
2(22,123) \\
3(36,109) \\
4(27,118)\end{array}$ & $\begin{array}{l}509-2,004 \\
2,042-3,238 \\
3,239-5,054 \\
5,162-38,896\end{array}$ & $\begin{array}{r}0-1,597 \\
1,600-2,667 \\
2,676-4,040 \\
4,047-49,879\end{array}$ & $\begin{array}{l}1.00 \\
0.70(0.38-1.28) \\
1.30(0.72-2.32) \\
0.89(0.48-1.66) \\
\text { trend } \mathrm{OR}=1.03(0.84-1.25) \mathrm{p}=0.79\end{array}$ \\
\hline Retinol, $\mu \mathrm{g} /$ day & $\begin{array}{l}1(32,140) \\
2(39,133) \\
3(36,136) \\
4(30,140)\end{array}$ & $\begin{array}{c}27-41 \\
345-631 \\
632-1,040 \\
1,041-3,769\end{array}$ & $\begin{array}{c}60-549 \\
555-945 \\
947-1,444 \\
1,445-5,231\end{array}$ & $\begin{array}{l}1.00 \\
1.24(0.69-2.24) \\
1.11(0.60-2.06) \\
0.85(0.44-1.64) \\
\text { trend OR }=0.93(0.75-1.14) \mathrm{p}=0.47\end{array}$ \\
\hline Calcium, mg/day & $\begin{array}{l}1(34,138) \\
2(34,138) \\
3(39,133) \\
4(30,140)\end{array}$ & $\begin{array}{c}226-723 \\
724-936 \\
941-1,173 \\
1,184-2,731\end{array}$ & $\begin{array}{r}250.0-743 \\
744-1,009 \\
1,010-1,234 \\
1,235-3,144\end{array}$ & $\begin{array}{l}1.00 \\
1.00(0.57-1.76) \\
1.13(0.61-2.09) \\
0.77(0.39-1.51) \\
\text { trend OR }=0.93(0.75-1.15) \mathrm{p}=0.51\end{array}$ \\
\hline Iron, mg/day & $\begin{array}{l}1(35,137) \\
2(26,146) \\
3(37,135) \\
4(39,131)\end{array}$ & $\begin{array}{c}4.7-9.7 \\
9.8-11.8 \\
11.9-14.4 \\
14.5-63.5\end{array}$ & $\begin{array}{r}4.7-11.5 \\
11.6-13.7 \\
13.8-16.8 \\
16.9-50.4\end{array}$ & $\begin{array}{l}1.00 \\
0.71(0.38-1.31) \\
1.10(0.57-2.12) \\
1.22(0.58-2.58) \\
\text { trend } \mathrm{OR}=1.12(0.88-1.43) \mathrm{p}=0.37\end{array}$ \\
\hline
\end{tabular}

flammatory bowel disease. PUFAs, which may be subdivided into $n-3$ and n-6 types, are present in cell membranes as predominantly eicosapentaenoic acid (n3 derived) and arachidonic acid ( $n-6$ derived). Both these molecules can be metabolised to prostaglandins, thromboxanes and leukotrienes, which have stimulatory effects on the immune system [25-27] and could stimulate colitis. The metabolites of arachidonic acid, including prostaglandin $\mathrm{E}_{2}$ and leukotriene $\mathrm{B}_{4}$ have more pronounced immuno-stimulatory effects than those derived from eicosapentaenoic acid, such as prostaglandin
$\mathrm{E}_{3}$ and leukotriene $\mathrm{B}_{5}$ [25-27]. These pro-inflammatory effects include aggregation, chemotaxis and release of lysosomal enzymes from neutrophils $[25,27]$. A high dietary intake of PUFAs, particularly n-6-derived compounds and their incorporation into colonic cell membranes would lead to a source of pro-inflammatory molecules which could hypothetically pre-dispose to ulcerative colitis. This PUFA hypothesis is consistent with the finding of increased levels of both arachidonic acid and its metabolites, $\mathrm{PGE}_{2}$ and leukotriene $\mathrm{B}_{4}$, in the colonic mucosa of patients with ulcerative colitis [28-30]. 
The degree of inflammatory cell infiltrate also correlated with the mucosal arachidonic acid concentration $(\mathrm{r}=$ $0.89, \mathrm{p}<0.05)$ in one clinical study [30]. Furthermore, the drugs used to treat ulcerative colitis, namely 5 -aminosalicyclic compounds, suppress $\mathrm{PGE}_{2}$ levels in a dosedependent manner [29]. The balance in the diet of $n-3$ and n-6 PUFAs may be important in the aetiology of ulcerative colitis, because of their differing immuno-stimulatory properties. An analysis of the different sub-types of PUFAs was not possible in this study, because not all centres currently have data available on the different classes, although this may be possible in the future. In other work, three case-control studies have investigated the intake of PUFAs prior to the development of ulcerative colitis, although by the nature of the study design, the possibility of recall bias needs to be considered $[9,12$, 15]. Such a study from Israel of 54 patients with ulcerative colitis, most of whom were diagnosed 3-4 months previously, showed that a high intake of polyunsaturated fatty acids increased the risk of ulcerative colitis by 6.54 times (95\% CI $=1.45-29.68)$ [12]. As the time interval between diagnosis and recruitment was short, reporting of pre-symptomatic diet was likely to be accurate. Similar results were obtained in a case-control study of 43 patients from Holland, all diagnosed within 5 months of recruitment, which reported an odds ratio of 5.1 (95\% CI 1.0-26.7) for the highest versus lowest tertile of intake [9]. However, an investigation from Japan showed no difference between cases and controls in the consumption of PUFAs, although here it is possible that the dietary information was less accurate as patients had to remember their pre-symptomatic diet up to three years previously [15]. Furthermore, the fraction of $n-3$ PUFAs, as a proportion of total PUFAs, is higher in the Japanese than the Western diet. Therefore, due to the lesser pro-inflammatory affects of $n-3 s$, compared to $n-6 s$, this would make it harder to detect differences in the total intake of PUFAs between cases and controls in the Japanese study. To help clarify whether the positive association with PUFAs reported in this cohort study is causative other investigations are required, including further prospective studies and randomised controlled trials of a low-PUFA diet in patients with established disease. This prospective study did not show any associations between other dietary constituents and ulcerative colitis. However, if effects do exist but are small, then analysis of more incident cases would be needed to detect these.

The investigation found no protective effect of an increased dietary intake of fibre in preventing the development of ulcerative colitis, although trials of fibre supple- mentation in patients with established disease have reported benefits [31, 32]. In a placebo-controlled trial of 29 patients, ispaghula husk was superior in relieving gastrointestinal symptoms in patients in remission $(\mathrm{p}<0.001)$ [31]. Also a higher rate of improvement was recorded in the intervention group ( $69 \%$ vs. $24 \%, \mathrm{p}<0.001)$. Similarly, in a trial of 22 patients with quiescent ulcerative colitis who took $20 \mathrm{~g}$ of dietary fibre, none suffered a relapse, there was no increase in symptoms during the trial and in patients reporting symptoms at baseline these significantly improved at 3 months [32]. If a protective effect of fibre does exist, then the mechanism may involve its conversion by colonic bacteria to butyrate which is an energy source for colonocytes. However, a trial of 35 patients comparing sulphasalazine without a change in diet against no sulphasalazine plus a high-fibre diet including bran supplementation, showed the former was superior in preventing relapse ( $20 \%$ vs. $75 \%$ relapse rate, $p=0.001$ ) [33]. Dietary factors may have different effects in both the aetiology of disease and secondly as treatments in patients with established disease. The response to a highfibre diet needs to be further investigated and clarified in both these areas.

The principal advantage of this investigation over previous case-control studies was the removal of recall bias, leading to dietary information which was not prone to be differentially biased for cases versus controls. However, a limitation of this work, as in case-control studies, is measurement error in recording diet, which probably resulted in an under-estimation of any associations including that of PUFAs. This error would mean that smaller associations, which may indeed exist, would go undetected. A more accurate method of assessing diet is weighed records of food intake, but these are impractical to use in large-scale epidemiological studies. A validation study, conducted in EPIC-Norfolk, UK, comparing dietary intakes between 16-day weighed records and food frequency questionnaires reported correlation coefficients between 0.39 and 0.90 for dietary variables [22]. Of particular relevance to the findings of this study was a Spearman correlation coefficient of 0.64 for fat intake. A further limitation of this study is that the marked protective effect of appendectomy on the risk of ulcerative colitis [34-36], could not be adjusted for due to incomplete information being available for this procedure. Possible, biological mechanisms for the negative association include that firstly removal of the appendix reduces the number of mesenteric lymph nodes, which may affect the balance between ileocolonic helper and suppressor lymphocyte function. Secondly, appendectomy 
would remove any infectious agent in the appendix if these were involved in the aetiology of ulcerative colitis. However, although adjusting for appendectomy may alter the results; this is probably unlikely as the procedure does not result in any recommended dietary change. Finally, the generalizability of any cohort study, namely its external validity, needs to be considered. The population studied in this investigation was predominantly middle aged to elderly, whereas ulcerative colitis is traditionally regarded to be a disease presenting in earlier life. However, a large incidence study of patients with ulcerative colitis presenting to centres across Europe, showed that for men the age at presentation was similar across all age groups, but for women the incidence declined with increasing age [37]. Therefore, our study had an under-representation of younger women with ulcerative colitis. Furthermore, a greater proportion of patients in this cohort investigation had more widespread disease than those in the European incidence study [38] (32\% vs. 21\% for patients with disease proximal to the splenic flexure, $\left.\chi^{2}=8.7, p=0.003\right)$.

In summary, this study found a marginally significant positive association between an increasing dietary intake of total PUFAs and ulcerative colitis. Measurement error may mean this effect is underestimated. This may be a causative association because of a plausible biological mechanism and supporting evidence from other biochemical and clinical investigations. The association could be further explored in future epidemiological studies in other populations and in randomised controlled trials assessing the efficacy of diets low in polyunsaturated fatty acids for treating patients with ulcerative colitis. Other smaller effects of diet may exist, but these were not detected because larger numbers of subjects need to be studied and secondly due to measurement error inherent in the food-frequency questionnaires.

\section{Acknowledgements}

The authors greatly acknowledge the residents in each centre who kindly participated in the study. This analysis was funded by The Sir Halley Stewart Trust, The National Association for Colitis and Crohn's Disease and The NHS Executive Eastern Region. EPIC-Norfolk is supported by Cancer Research UK, The Medical Research Council, The British Heart Foundation, The Food Standards Agency, The Department of Health, and The Academy of Medical Sciences. EPIC-Oxford is supported by Cancer Research UK and The Medical Research Council. EPIC-Malmö is supported by The Swedish Cancer Society, The Swedish Research Council and The Region of Skane. EPIC-Denmark is supported by The Danish Cancer Society. EPIC-Heidelberg is supported by 'Stiftung Landesbank Baden-Württemberg'. EPIC-Potsdam is supported by Federal Ministry of Research and Technology, European Union and Deutsche Krebshilfe. EPIC-Florence is supported by The Associazione Italiana per la Ricerca contro il Cancro (AIRC-Milan) and Regione Toscana.

\section{References}

1 Eaden JA, Abrams KR, Mayberry JF: The risk of colorectal cancer in ulcerative colitis: a meta-analysis. Gut 2001;48:526-535.

2 Baron S, Turck D, Leplat C, Merle V, GowerRousseau C, Marti R, Yzet T, Lerebours E, Dupas JL, Debeugny S, Salomez JL, Cortot A, Colombel JF: Environmental risk factors in paediatric inflammatory bowel diseases: a population based case-control study. Gut 2005;54:357-363.

3 Brauer PM, Gee MI, Grace M, Thomson ABR: Diet of women with Crohn's disease and other gastrointestinal diseases. J Am Diet Assoc 1983;82:659-664.

4 Jarnerot G, Jarnmark I, Nilsson K: Consumption of refined sugar by patients with Crohn's disease, ulcerative colitis and irritable bowel syndrome. Scand J Gastroenterol 1983;18:999-1002.

5 Thornton JR, Emmett PM, Heaton KW: Diet and ulcerative colitis. BMJ 1980;i:293-294.
6 Thornton JR, Emmett PM, Heaton KW: Smoking, sugar, and inflammatory bowel disease. BMJ 1985;290:1786-1787.

7 Tragnone A, Valpiani D, Miglio F, Elmi G, Bazzocchi G, Pipitone E, Lanfranchi GA: Dietary habits as risk factors for inflammatory bowel disease. Eur J Gastroenterol Hepatol 1995;7:47-51.

8 Gee MI, Grace M GA, Wensel RH, Sherbaniuk RW, Thomson ABR: Nutritional status of gastroenterology out-patients: comparison of inflammatory bowel disease with functional disorders. J Am Diet Assos 1985; 85:1591-1599.

9 Geerling BJ, Dagnelie PC, Badart-Smook A, Russel MG, Stockbrugger RW, Brummer RJM: Diet as a risk factor for the development of ulcerative colitis. Am J Gastroenterol 2000;95:1008-1013.

10 Panza E, Porro GB: Smoking, sugar and inflammatory bowel disease. BMJ Clin Res Ed 1985;291:971-972.
11 Persson PG, Ahlbom A, Hellers G: Diet and inflammatory bowel disease: a case-control study. Epidemiology 1992;3:47-52.

12 Reif S, Klein I, Lubin F, Farbstein M, Hallak A, Gilat T: Pre-illness dietary factors in inflammatory bowel disease. Gut 1997;40: 754-760.

13 Rosman-Urbach M, Niv Y, Birk Y, Morgenstern S, Schwartz B: Relationship between nutritional habits adopted by ulcerative colitis relevant to cancer development patients at clinical remission stages and molecular-genetic parameters. Br J Nutr 2006;95:188195.

14 Russel MG, Engels LG, Muris JW, Limonard CB, Volovics A, Brummer RJ, Stockbrugger RW: Modern life in the epidemiology of inflammatory bowel disease: a case-control study with special emphasis on nutritional factors. Eur J Gastroenterol Hepatol 1998;10: 243-249. 
15 Sakamoto N, Kono S, Wakai K, Fukuda Y, Satomi M, Shimoyama T, Inaba Y, Miyake Y, Sasaki S, Okamoto K, Kobashi G, Washio M, Yokoyama T, Date C, Tanaka H: Dietary risk factors for inflammatory bowel disease: a multi-centre case-control study in Japan. Inflamm Bowel Dis 2004;11:154-163.

16 Brandes JW, Stenner A, Martini GA: Dietary habits of patients with ulcerative colitis. Z Gastroenterol 1979;12:834-842.

17 Tragnone A, Hanau C, Bazzocchi G, Lanfranchi GA: Epidemiological characteristics of inflammatory bowel disease in Bologna, Italy: incidence and risk factors. Digestion 1993;54:183-188.

18 Riboli E: Nutrition and cancer: background and rationale of the European Prospective Investigation into Cancer and Nutrition. Ann Oncol 1992;3:783-791.

19 Bingham S, Riboli E: Diet and cancer: the European Prospective Investigation into Cancer and Nutrition. Nat Rev Cancer 2004 4:206-215.

20 Kaaks R, Slimani N, Riboli E: Pilot phase studies on the accuracy of dietary intake measurements in the EPIC project: overall evaluation of results. European Prospective Investigation into Cancer and Nutrition. Int J Epidemiol 1997;26:S26-S36.

21 Margetts BM, Pietinen P: European Prospective Investigation into Cancer and $\mathrm{Nu}$ trition: validity studies on dietary assessment methods. Int J Epidemiol 1997;26: S1-S5.

22 Bingham SA, Gill C, Welch A, Cassidy A, Runswick S, Oakes S, Luben R, Thurnham DI, Key T, Roe L, Khaw KT, Day NE: Validation of dietary assessment methods in the UK arm of EPIC using weighed records and 24 hour urinary nitrogen and potassium and serum vitamin $\mathrm{C}$ and carotenoids as biomarkers. Int J Epidemiol 1997;26(suppl 1): S137-S151.
23 Logan RFA, Kay CR: Oral contraception, smoking and inflammatory bowel disease findings in the Royal College of General Practitioners Oral Contraception Study. Int J Epidemiol 1989;18:105-107.

24 Calkins BM: A meta-analysis of the role of smoking in inflammatory bowel disease. Dig Dis Sci 1989;34:1841-1854.

25 Lee TH, Mencia-Huerta IM, Shih C, Corey EJ, Lewis RA, Austen KF: Characterization and biological properties of 5,12-dihydroxy derivatives of eicosapentaenoic acid, including leukotriene B5 and the double lipoxygenase product. J Biol Chem 1984;259:23832389.

26 Heller A, Koch T, Schmeck J, Van Ackern K: Lipid mediators in inflammatory disorders. Drugs 1998;55:487-496.

27 Goldman DW, Pickett WC, Goetzl EJ: Hu man neutrophil chemotactic and degranulating activities of leukotriene B5 (LTB5) derived from eicosapentaenoic acid. Biochem Biophys Res Comm 1983;117:282-288.

28 Sharon P, Stenson WF: Enhanced synthesis of leukotriene B4 by colonic mucosa in inflammatory bowel disease. Gastroenterology 1984;86:453-460.

29 Sharon P, Ligumsky M, Rachilewitz D, Zor $\mathrm{U}$ : Role of prostaglandins in ulcerative colitis: enhanced production during active disease and inhibition by sulfasalazine. Gastroenterology 1978;75:638-640.

30 Nishida T, Miwa H, Shigematsu A, Yamamoto $\mathrm{M}$, Iida $\mathrm{M}$, Fujishima $\mathrm{M}$ : Increased arachidonic acid composition of phospholipids in colonic mucosa from patients with active ulcerative colitis. Gut 1987;28:1002-1007.
31 Hallert C, Kaldma M, Petersson BG: Ispaghula husk may relieve gastrointestinal symptoms in ulcerative colitis in remission. Scand J Gastroeneterol 1991;26:747-750.

32 Hallert C, Bjorck I, Nyman M, Pousette A, Granno C, Svensson H: Increasing fecal butyrate in ulcerative colitis patients by diet: controlled pilot study. Inflamm Bowel Dis 2003;9:116-121.

33 Davies P, Rhodes J: Maintenance of remission in ulcerative colitis with sulphasalazine or a high-fibre diet: a clinical trial. BMJ 1978 1524-1525.

34 Gilat T, Hacohen D, Lilos P, Langman M: Childhood factors in ulcerative colitis and Crohn's disease: an international cooperative study. Scand J Gastroenterol 1987;22: 1009-1024

35 Koutroubakis I, Vlachonikolis I: Appendectomy and the development of ulcerative colitis: results of a metaanalysis of published case-control studies. Am J Gastroenterol 2000;95:171-176

36 Rutgeerts P, D'Haens G, Hiele M, Geboes K, Vantrappen G: Appendicectomy protects against ulcerative colitis. Gastroenterology 1994;106:1251-1253.

37 Shivananda S, Lennard-Jones JE, Logan R, Fear N, Price A, Carpenter L, Van Blankenstein M, EC-IBD Study Group: Incidence of inflammatory bowel disease across Europe: is there a difference between north and south? Results of the European collaborative study on inflammatory bowel disease (ECIBD). Gut 1996;39:690-697.

38 Lennard-Jones JE, Shivananda S: Clinical uniformity of inflammatory bowel disease at presentation and during the first year of disease in the north and south of Europe. ECIBD Study group. Eur J Gastroenterol Hepatol 1997;9:353-359. 